\title{
Venue Shift Following Devolution: When Reserved Meets Devolved in Scotland
}

This article examines the means used to address blurred or shifting boundaries between reserved UK and devolved Scottish policy. It outlines the main issues of multi-level governance and intergovernmental relations in Scotland and the initial problems faced in identifying responsibility for policy action. While it suggests that legislative ambiguities are now mainly resolved with the use of 'Sewel motions', it highlights cases of Scottish action in reserved areas, including the example of smoking policy in which the Scottish Executive appears to 'commandeer' a previously reserved issue. However, most examples of new Scottish influence suggest the need for UK support or minimal UK interest.

\section{Intergovernmental Relations and Multi-Level Governance}

A common theme of devolution and federalism studies is the entanglement of policy issues when decision-making power is vested in more than one actor. Although most political systems outline in detail the policy domains of each level or type of government, it is inevitable that the boundaries between policy areas will become blurred in practice. There are two relevant approaches to this area of study. The first - widespread in the literature on intergovernmental relations - highlights country level differences according to institutional structures, power and the recourse to established authority and formal resolution. This literature may be used to explore the structure of UK relations - is it a unitary or union state? Can it be meaningfully compared with federal, quasi-federal or other devolved unions? What is the strength of the centre and what is the frequency of formal dispute resolution? (e.g. Mitchell, 2003; Watts, forthcoming; Horgan, 2004; Agranoff, 2004). The second - associated with the literature on multi-level governance - highlights informal relationships and the blurring of boundaries between public/ private action and levels of governmental sovereignty. Decision-making authority is dispersed and policy outcomes are determined by a complex series of negotiations between state and private interests (see e.g. Bache and Flinders, 2004a; 2004b; Hooghe and Marks, 2003a; 2003b). 
A combination of approaches highlights a more widespread finding in the political science literature - that the identification of power in terms of capacity is limited without demonstration of the exercise of power (Hindess, 1995). This includes the overt use of power to make decisions in the face of opposition. It also includes discussions of agenda-setting and the exercise of power to limit the scope of those decisions. As Baumgartner and Jones (1993: 32) suggest, this often involves competition to define policy problems in a certain way to ensure that they are dealt with in a particular decision making 'venue'. The focus of analysis moves, from the capacity to make decisions, to the level of government in which the decisions are made. Therefore, the complexity of governance arrangements and subsequent competition to ensure decision-making jurisdiction makes it difficult to predict policy outcomes from the analysis of institutional arrangements alone. This reinforces the need for case study analysis - by country to explore the effect of institutions and formal arrangements, by policy area to ensure that relationships identified in one field are not atypical, and over time to explore the shifting boundaries between policy areas. To address a tendency to interpret intergovernmental outcomes in terms of the powers of its dominant participants, these case studies should also present competing 'narratives' of policy change (see Bevir and Rhodes, 1999).

This article outlines the case of Scotland and the factors underlying its legislative relationship with the UK since 1999. The findings support two narratives of policy development. First, the most common means to address blurred legislative boundaries has been the 'Sewel motion' which gives Scottish Parliamentary consent for Westminster to legislate. The UK arena is therefore the most likely venue for decision making or dispute resolution. This supports a 'top-down' narrative of UK dominance, which suggests that the informality of intergovernmental relations is based on a balance of power towards Whitehall. Second, there is scope for policy autonomy through shifting the boundaries of the devolution settlement. This supports a 'bottom-up' narrative which highlights a strategy of reframing and downplaying issues to ensure that they are dealt with in a devolved decision-making venue. A combination of narratives suggests that while UK power is often exaggerated by focussing on a very small number of visible 
conflicts, the scope for Scottish success depends on political will, the level of UK interest, and the strength or visibility of the agenda surrounding each policy issue.

\section{Reserved and Devolved Areas in Scotland}

The Scotland Act 1998 specifies which matters are reserved. Devolved matters are those areas not specified in the Act, as well as some extra powers granted on an ad hoc basis (such as the Scottish rail network in 2004).

Table 1 Reserved and Devolved Policy Areas

\begin{tabular}{|l|l|}
\hline Policy Areas Reserved & Policy Areas Devolved \\
\hline International relations & Health \\
\hline Defence & Education and training \\
\hline Fiscal and monetary policy & Economic development \\
\hline Immigration and nationality & Local government \\
\hline Drugs and firearms & Police and prisons \\
\hline Regulation of Elections & Fire and ambulance services \\
\hline National security & Social work \\
\hline Employment & Housing and planning \\
\hline Company law & Transport \\
\hline Consumer Protection & Law and home affairs \\
\hline Social Security & Environment \\
\hline Regulation of professions & Agriculture, fisheries, forestry \\
\hline Energy/ nuclear safety & Sport \\
\hline Air transport, road safety & The arts \\
\hline Consumer Protection & Devolved research, statistics \\
\hline Gambling & \\
\hline Equality & \\
\hline Human reproductive rights & \\
\hline Copyright Law & \\
\hline Broadcasting & \\
\hline
\end{tabular}

Source: adapted from Keating (2005: 22)

While table 1 suggests that these boundaries are reasonably clear, initial governmental uncertainty caused some embarrassingly public confusion. For example, Scotland's Deputy Minister for Justice made 2 press statements on 24th July 2000. The first vowed to 
aid central government in the development of the Register of Sex Offenders since this involved a reserved power. The second explained that the register was a devolved responsibility (Rhodes et al, 2003: 97). Early confusion over competence was also exploited. As Parry and Jones (2000) discuss, the lack of a dedicated industry minister in the Scottish Executive allowed Scotland Office intervention in industrial policy, including the highly publicised saving of the Kvaerner shipyard in Glasgow. ${ }^{1}$ While such teething troubles are now healing, there are still blurred boundaries of competence, often complicated by the EU dimension. For example:

- Although environmental and agricultural policy is devolved, half of all consultation documents issued by the Scottish Executive in these areas relate to EU directives. ${ }^{2}$ The Scottish Executive has delegated responsibility for implementing EU directives but the UK is still the member state and formally responsible.

- Even when devolved areas such as health are relatively clear there are still EU and UK influences, such as the Working Time Directive on clinical cover in rural areas and the new Consultant and GP contracts (see Greer, 2005a and 2005b). Medical training and regulation are reserved and groups such as the medical Royal Colleges still focus on the UK.

- The role of professions ensures that devolved areas such as higher education and social work maintain a UK focus.

- UK involvement in Scottish policy is furthered by the reserved nature of the civil service as well as cross-cutting or 'joined up government' initiatives and the reservation of fiscal policy and social security. For example, housing policy is devolved but housing benefit and funding for supported housing is reserved, while Treasury rules on local authority borrowing constrain any alternative to housing stock transfer.

- Although the Scottish Executive may attempt to address fuel poverty, it can only influence levels of insulation and heating in homes, not the price of fuel or the level of income tax/ benefits. 
- The means to address matters such as child poverty in Scotland also operates within the context of reserved income tax and benefits regimes. Many policy responses are second order, focussing on access to devolved public services.

- The overlap of responsibilities is most apparent in the implementation of reserved policies by devolved services. For example, the Home Office directs Scottish local authorities on immigration and controls the use of 'dawn raids' by police forces when removing unsuccessful asylum seekers (Cairney, 2006a: 19).

As Keating discusses (2005: 18; see also Simeon, 2003: 216), these issues of territorial politics are common to modern federal systems with the dual aim of devolving decisions and maintaining central control when appropriate. The differences arise in country-level structures and the means used to address these overlaps. In the UK the unusual nature of the former affects the latter. The UK is asymmetrical in two senses - first because devolution was extended to a relatively small share of the population, with Scotland (8.6 per cent), Wales (4.9 per cent) and Northern Ireland (2.9 per cent) accounting for 16.4 per cent; and second because the balance of power is tipped towards UK policy departments dealing predominantly with the English population. As Keating (2005: 120) suggests, the centre is faced with a small set of devolved governments which do not match the powers of federated or devolved authorities in other countries such as Germany, Spain, Belgium or Canada. Scotland is not part of a collection of powerful regions and the UK does not have a 'supreme constitution' guaranteeing a level of autonomy for devolved governments (Watts, forthcoming).

In the UK, intergovernmental relations are conducted almost entirely through executives (rather than parliaments) and while there are formal mechanisms to resolve disputes, the tendency is not to use them. There have been no references of Scottish bills to judicial review since this is treated as a last resort and the Scottish Executive is more likely to 'remove offending sections' than face delay (Page, 2005). The Joint Ministerial Committee (JMC) was designed to allow central government to call a meeting with the territories to discuss issues of working arrangements, the impact of devolved policy on reserved areas and vice versa, share experience and consider disputes. However, this has 
also met infrequently (Trench, 2004). As Horgan (2004: 122) suggests, there is even an 'informal flavour' to formal concordats since - as in Canada and Australia - these are not legally binding. Further, many avenues for public disagreement have been closed by the maintenance of the Barnett ${ }^{3}$ system of finance, links between UK civil servants and the shared party of government (Keating, 2005: 122-3).

The role of parties in IGR varies considerably, from Canada with a devolved party structure and differentiated party competition by territory, to Germany which has integrated parties and formal links to coordinate policy (Horgan, 2004: 122). In the UK there are few signs of formal links and the most important are based on personal relationships (2004: 124). However, such links do not necessarily translate to policy convergence since the relatively assertive Henry McLeish was a former UK minister while the relatively risk-averse Jack McConnell was not a Westminster MP. The waters are also muddied in Scotland by coalition government and the highest profile disputes have resulted from divergent policies associated with the Liberal Democrats (Labour's coalition partners). However, more recent experience in Wales suggests that, even in the absence of coalition, UK and devolved policy convergence is not certain. The effect of territorial electoral pressures and different policy conditions undermines the scope for UK party direction. Therefore, the informal use of IGR through parties may reflect a desire to avoid political embarrassment and present a united front rather than a means to secure convergence in policy aims.

\section{The top-down narrative: intergovernmental relations, disputes and Sewel motions}

The top-down narrative suggests that this informality in IGR is based on a balance of power towards Whitehall and Scottish reluctance to risk its position by pursuing conflicting interests in public. Trench (2004: 513) suggests that the lack of JMC meetings reflects UK disinterest: ' $\ldots$ a clear indicator that devolution is no longer a prime concern of the Prime Minister and other politicians ... they have disentangled themselves from devolution' (2004: 515-6). Similarly, Keating (2005: 125) suggests that actors in Whitehall often forget about Scotland and neglect to consult, then make statements on 
UK policy without a Scottish qualification or opt-out. The structure and frequency of IGR may therefore be more about UK dominance than consensus.

This imbalance of power is apparent when disputes rise to the surface. The most high profile policy of the first Scottish Parliament session (1999-2003) was the decision in Scotland to depart from the UK line and implement the recommendations of the Sutherland Report on 'free' personal care for the elderly. The practical effect was to give a non-means-tested payment of $£ 145$ per person per week for those who qualified for personal care and an extra $£ 65$ for those who qualified for nursing care (Keating et al, 2003). However, these payments removed the entitlement of recipients to the UK Attendance Allowance (£38-56) and the Treasury refused to give their saving to the Scottish Executive ( $£ 22$ million). As Simeon (2003: 225) suggests, if the UK government had been sympathetic to the policy a solution would have been found, but general Whitehall indifference to Scotland had turned to specific hostility (particularly since UK ministers failed to persuade their Scottish counterparts to maintain a UK line). This approach was also taken with the issue of Hepatitis C compensation in Scotland, with the Department of Work and Pensions threatening to reduce benefit payments to those in receipt of Scottish Executive compensation (Lodge, 2003). This case was taken further, with Whitehall delaying Scottish payments on the basis of competence (health devolved, but compensation for injury and illness reserved) until it came up with a UKwide scheme to be implemented in Scotland. ${ }^{4}$

Scottish policy on higher education fees also marked a clear departure from the UK line, but the extent of divergence was constrained by reserved elements. The Scottish Executive proposed to allow students to defer a $£ 2000$ payment until they had reached a certain income level following graduation. While a key recommendation of the Cubie Report (on which the policy was based) was a repayment of $2 \%$ of income at an income level of $£ 25000$, this was constrained by existing arrangements in which the Inland Revenue collected the fees and student loan payments. The Scottish Executive may have been able to set up a separate system for fee collection, but it could not opt-out of the reserved arrangements for student loan payments, which at the time began at $9 \%$ of 
income over $£ 10000$ per year. It therefore deemed the costs to be greater than the benefits and accepted the lower threshold (until this was raised to $£ 15000$ in the UK by the Higher Education Act 2004).

The administration of EU structural funds also demonstrates strong Treasury power. As Keating (2005: 152) suggests, the European Commission has 'found allies' in regions keen on this additional funding without central government control - particularly since the money granted must be seen to be spent and matched by the recipient region. However, as Bell and Christie (2001: 147; 2005: 168) discuss, the UK as the member state negotiates the funding and treats this as Treasury money (since the UK is still a net contributor to the EU). So any money granted by the EU to Scotland is paid to the Treasury which includes this payment within the existing Barnett settlement. The result is that not only does Scotland get no more money, but it also has to devote the agreed amount to the relevant project and find matching funding from within its existing budget. Similar measures may also be used if the Scottish Executive attempts to raise more money through business rates or local authority taxes - the Treasury could merely reduce the Scottish settlement by the same amount and remove the incentive to raise money beyond acceptable limits. As a result, Treasury power in raising money combined with incrementalism (regarding Scotland's existing financial commitments) constrains policy initiation in Scotland if it has a significant spending element (Bell and Christie, 2001; Mitchell, 2004).

\section{UK Legislation as the default action}

This dominance extends to legislation and legislative procedure. As Hazell suggests, Westminster produces more legislation for Scotland than the Scottish Parliament does $50 \%$ more bills per annum of primary legislation and double the amount of subordinate

legislation. ${ }^{5}$ Further, the most common legislative means to address blurred boundaries between reserved and devolved issues has been the use of 'Sewel motions', named after Lord Sewel, the minister responsible for ensuring the progress of the Scotland Bill through the House of Lords in 1998 (Winetrobe, 2001). The procedure was created in anticipation of a small number of instances in which the UK government would legislate 
in devolved areas, and a Sewel motion is passed by the Scottish Parliament to give Westminster the authority to legislate on devolved matters. As Winetrobe (2005) discusses, confusion has arisen over the types of measures taken on the authority of a Sewel motion, since a Westminster Act can also authorise a change in Scottish legislative functions or a change in Scottish Executive functions (to avoid confusion, this article refers to the latter as 'reverse-Sewel' motions since they represent a form of executive devolution rather than a perceived loss of Scottish powers).

As Cairney and Keating (2004) and Cairney (2005a) discuss, there were 50 motions passed from 1999 to April 2005 (excluding 13 reverse-Sewel motions - see below). 31 were justified mainly on the basis of entangled responsibilities. Legislation relating to crime is a frequent category given its height on the UK's agenda and the potential for legal loopholes. For example, with legislation on an international criminal court, powers of arrest are devolved, but extradition is reserved and with the Proceeds of Crime Act drug trafficking, money laundering and taxation are reserved, whilst other civil and criminal matters are devolved. In other areas, domestic policy may have an international element, such as arrangements for adoption requiring an approved list of countries, or the licensing of firework displays and importation of fireworks. There are also cases such as gender recognition and civil partnerships where the issues seem to relate to devolved competence, but a Sewel motion is passed to deal with reserved elements such as the extension of benefits and pension rights. Fourteen motions relate to reserved bodies operating in devolved areas or minor administrative anomalies. These cases foster a UKwide approach to maintain consistency of standards. The areas involved - such as food standards, financial services, race relations, health protection and serious organised crime - tend to be devolved but with the potential for UK bodies to act in Scotland. Five Sewel motions were justified mainly in terms of expediency (removing the need for identical legislation in Scotland) and/ or the need for political uniformity (although most motions involve this element). These include urgent measures related to terrorism, but also to measures on postal voting in local elections and the recovery of National Health Service (NHS) costs. 
Rising dissatisfaction of opposition parties with the Sewel process prompted a Procedures Committee inquiry into the issue in 2005. The report highlighted the need for more information on the timing and substance of motions, an 'early warning' system to ensure more committee deliberation and more time for plenary debate with the more significant motions (this was subsequently endorsed by Westminster's Scottish Affairs Select Committee, 2006: 18). In other words, the Procedures Committee (2005) reinforced the idea that Sewel (or 'legislative consent') motions are now routine measures of government and the chosen legislative means of addressing blurred boundaries. This suggests a degree of UK dominance of these issues. Not only has there never been an instance in which a Sewel motion resolution has been defeated, but there is also no certainty that such a defeat would stop Westminster from legislating. Since it does not need formal permission from the Scottish Parliament to legislate in devolved areas, 'it would be for Westminster to decide whether to legislate on that matter notwithstanding the lack of consent' (Clerking and Reporting Directorate, 2002: 1).

\section{The Bottom-up Narrative: finance, executive devolution and creating policy space}

The 'bottom-up' narrative suggests that it is easy to overplay the significance of UK constraints by focussing on a very small number of visible conflicts. Scottish power is more subtle and apparent in less formal arrangements. For example, there is potential to influence UK foreign policy, ${ }^{6}$ while the Scottish Executive supplements its limited formal rights in the EU with informal channels of contact and influence (as did the Scottish Office before it - see Bulmer et al, 2002). Power is also manifest in the level of discretion Scotland enjoys (for example, during the implementation of EU directives). Day-to-day policy making takes place in the context of financial arrangements conducive to autonomy, while more and more decisions over the detailed direction of policy in reserved areas are devolved to the Scottish Executive. This 'executive devolution' was apparent before political devolution, but it has now been enhanced by the Scottish Parliament's legitimacy and the greater powers granted to Scottish ministers since 1999. In addition, the example of smoking legislation highlights the scope for reframing issues to ensure venue shift. 
The bottom-up narrative suggests that UK disinterest does not equate with dominance. If Whitehall ministers have 'disentangled themselves from devolution', then scope exists for day-to-day autonomy, particularly since Scotland does not suffer from the lack of investment that Bulpitt (1983: 139) associates with the centre's neglect of the periphery. While Scotland appears to lose the public arguments over finance, this should be seen within a wider context of spending negotiations. Part of the reason that the Scottish Executive did not pursue the issue on free personal care is that it received a more favourable response from the Treasury on interest charges for loans for council housing, 'worth more than the amount of attendance allowance at stake' (Trench, 2005: 11). As Midwinter (2004: 139) discusses, the Scottish Executive received almost $£ 1$ billion to promote community ownership of council housing on top of the amount agreed through Barnett. ${ }^{7}$ While debate in Scotland often centres on the 'Barnett squeeze', or convergence over time between Scottish and English spending, the formula masks a process in which the Scottish Executive maximises its funding by stretching Treasury rules to their limits (interview, Scottish Executive, May 2005). Successive Treasury 'victories' over major policy areas, coupled with the appearance of reduced Scottish advantage over time may indeed suit both executives, since Scotland works 'behind the scenes' to supplement its income through side deals and by exaggerating the comparability of Scottish and English spending to maximise Barnett consequentials (interview, Scottish Executive, May 2005; see Keating, 2005 for a pre-devolution discussion). ${ }^{8}$

The nature of Barnett allows relative autonomy in Scottish spending and as Midwinter (2004) suggests, since the Scottish budget process would be incremental regardless of the type of funding mechanism, we should examine change at the margins to determine Scottish differences. In this light, Scotland has directed significant levels of funding to other policy areas. Further, since terms such as 'health' and 'education' are so broad, the Scottish Executive can pursue different policies as long as they are broadly in line with Whitehall spending commitments (Midwinter, 2004; Greer, 2004). No concerted effort has been made by the Treasury to ensure the consistency of expenditure statistics and since most policies have elements of a number of policy areas, you can 'call outputs what 
you like', according to the priorities of the UK government and Scottish population (interview, Scottish Executive, 2005). For example, while it would be unwise for the Scottish Executive to spend healthcare consequentials elsewhere, there is scope for a public health focus with spending directed through local government rather than the NHS (interview, Scottish Executive, 2005; Keating, 2005).

Such discussions are reminiscent of pre-devolution debates on the existence of a 'Scottish Political System' (Kellas, 1973; Paterson, 1994). Kellas (1973) describes the likelihood of autonomy (in policy areas left distinct following the Union) if levels of central government attention and potential for political embarrassment are low. This depends on the ability of Scottish actors to frame issues as technical or humdrum while minimising the appearance of policy divergence (as in the much fêted social work reforms of the 1960s). Success ensures limited Whitehall attention and hence some level of day-to-day autonomy, through the discretion involved in implementing policy and directing spending priorities. This was supplemented in the UK arena by the Scottish Office securing an agreed line with Scottish interests and acting as the UK's largest pressure group (Midwinter et al, 1991). Many of these arrangements still exist and the unwillingness of the Scottish Executive to 'rock the boat' suggests that it still employs resources to secure favourable policy outcomes in private (for example, the Scottish proportion of the UK spend is still comparable to pre-devolution levels - see Midwinter, 2004). Further, the increased ability of the Scottish Executive to go its own way on policy allows Scotland to influence UK decisions. Indeed, the example of Hepatitis $\mathrm{C}$ is one of a number of policies (including up-front tuition fees, charging volunteers for background firearm checks and tobacco advertising) in which Scottish Executive decisions have 'forced the hand' of UK ministers (Cairney, forthcoming).

\section{Executive Devolution}

The Scottish Office and Secretary of State for Scotland were first introduced in the late $19^{\text {th }}$ century as a symbolic gesture to address nationalistic grievances over the way the Union was handled in London. The office grew much more than anticipated following the precedent set by its introduction - that when Scotland's policy circumstances are 
different, Scotland's response and administrative arrangements should be different. As a result, although policy was decided at the UK level (with Scottish representation in Cabinet), the power to implement and shape public policy was routinely given to Scottish ministers (Kellas, 1973; Paterson, 1994; Mitchell, 2003; Keating, 2005). It is in this context that we can view 'reverse-Sewel' motions which describe Westminster Acts altering the functions of Scottish Executive ministers, allowing them to introduce secondary legislation or guidance on specified reserved matters. This type of executive devolution existed before 1999 and was a feature of the initial transfer of functions following the Scotland Act 1998 (see Himsworth, 2004: para 29 which discusses the main pre-devolution instrument - the Order in Council under s63 of the Scotland Act). However, there are now significant differences in the use of executive devolution. Most pre-devolution accounts stress the ability to tailor Scottish policy after UK formulation by using the scope afforded by a separate Scottish legal system, administrative structure and need for more time to implement (Cairney, 2002). There were few clear examples of Scottish policy initiation. However, following devolution such powers can be supplemented by the legitimacy granted for Scottish action. The Scottish Executive has become a figurehead for a Scottish electorate and issues such as nuclear power and asylum demonstrate pressure on Scottish ministers to act even when their responsibilities are not clear.

\section{Creating Policy Space in Scotland}

Scottish Executive legislation in 2005 to ban smoking in public places marked a clear departure from the UK approach and was criticised by the UK Secretary of State for Health (Cairney, forthcoming). ${ }^{9}$ Further, previous attempts (2003-4) to legislate by Stewart Maxwell MSP highlight the reserved nature of this policy. Maxwell was advised never to mention workplaces in the same sentence as the legislation to avoid legal challenge in the future. It was also suggested to Maxwell (by a Scottish Executive minister) that a Sewel motion was necessary to address reserved aspects of smoking policy and the prospect of a private legal challenge. Indeed, as recently as 2003 Scottish Executive civil servants would not discuss a smoking ban with interest groups because they deemed it outside their competence. The smoking ban in Ireland (which inspired 
Scottish policy change) is based on health and safety and employment law (with, for example, bars classed as workplaces rather than public places). Both are reserved issues in the UK and the concordat between the Health and Safety Executive and the Scottish Executive reflects this: 'The regulation of smoking and passive smoking in work places is a reserved matter'. ${ }^{10}$ This constraint is acknowledged in the Scottish Executive's tobacco action plan A Breath of Fresh Air (Scottish Executive 2004a: 26) and in its consultation document (Scottish Executive, 2004b): 'Any laws restricting smoking in the workplace on the basis of health and safety would need to be legislated for at the Westminster Parliament on a UK basis.' Yet the Scottish Executive did legislate and the draft regulations list workplaces as part of their definition of coverage. Some effort to reframe the issue was therefore necessary to shift the boundaries between devolved and reserved. As the Chief Medical Officer of the Scottish Executive (May, 2005) recounts:

I was clear that the tobacco issue was big and had to be tackled. It is for someone else to tell me how to do it. In the run up to A Breath of Fresh Air [published January 2004] I didn't have a clue what the legislative vehicle would be! There was talk of local government measures or the environmental health control/ substances hazardous to health legislation which was there already. Then the clever people in the legal department came up with public places. This is the right way to do it. What we want to do is make the law the servant of the policy and not the other way around. Stuff the law - let it catch up with us! So there is a big lesson from smoking - a new way of politics.

A similar approach emphasising the need to reframe the basis for policy action is expressed by Action on Smoking and Health Scotland and Maxwell, while one Scottish Executive civil servant confirms the attention to this issue before legislation:

There was a lot of consideration of whether the bill would be competent. If (as in Ireland) it was based on the workplace then we could not do it. So it had to be done on public health grounds. We can do a lot of things in this way. There is little you can't get at and a huge raft of things you can do. It effectively comes down to: is 
there a will? The law is effectively definitional - so one man's workplace is another man's public space (interview, May 2005)

There is some debate about the reserved status of smoking, with health ministers in Scotland arguing that this was never an issue in Whitehall and that Scottish Executive legal advice did not present any worries over competence if the bill was restricted to public health language. In this light, smoking is the most prominent example of the use of the 'purpose test' in Scotland to determine the true nature of a piece of legislation. ${ }^{11}$ While the legislation affected reserved areas (health and safety; employment), the primary aim of the legislation was to pursue public health measures. The purpose test has also been used more frequently for statutory instruments, suggesting that it has become a routine measure of government (with most blurred boundaries quietly addressed by civil servants). Yet this disguises the extent of reframing required to demonstrate the primacy of purpose, since in other countries the primary driver for a smoking ban has been health and safety. Indeed, when a similar ban was introduced in England a year later, the driver for comprehensive measures was MP concern over the health and safety of bar workers if pubs or private clubs were exempt from legislation.

\section{Combining Narratives: Sewel motions and constrained autonomy}

The top-down narrative situates a discussion of Sewel motions within the broader context of UK IGR dominance. They are used routinely, have never been defeated and such defeat would not necessarily stop Westminster from legislating. Yet, this is a political mechanism and the implications of a defeat would be more significant than the constitutional position suggests (Clerking and Reporting Directorate, 2002: 1). There is also significant debate around Sewel motion initiation and whose interests they serve. Page and Batey (2002: 513) suggest that most policy initiation comes from the 'administration of a UK statute book' since Scotland has a relatively small administration and number of statutes. The Scottish Executive's (unpublished) guidance on Sewel 'makes clear that most proposals for Westminster legislation in the devolved areas come from UK departments rather than Scottish ministers' (2002: 516). This proposal comes

after the legislative slot has been secured and gives Scotland little time to consider the 
issue. So while there is no public evidence of unwillingness to cooperate, Scottish ministers 'may find themselves effectively forced to agree to Westminster legislation in the devolved areas' given the uncertainty over devolved government powers and the prospect of the UK government referring the issue to the Judicial Committee of the Privy Council (Page, 2002). This interpretation contrasts with the Scottish Executive's insistence that most Sewel initiation comes from the Executive. Sewel selection is a pick'n'mix affair following informal contacts and an analysis of upcoming Westminster legislation. ${ }^{12}$ While the latter may exaggerate Scottish influence, it is in the interests of both governments for the process to appear seamless, allowing loopholes to be closed and reducing the likelihood of challenge in the courts (Cairney and Keating, 2004). The Sewel procedure is a convenient tool for a Scottish Executive short of parliamentary time, in broad agreement with the aims of the legislation, and in some cases anxious not to be seen 'lagging behind' England (Page and Batey, 2002: 513-14). Therefore, in many ways the Sewel process says more about executive-legislative than UK-Scottish relations and much of the parliamentary criticism of Sewel has arisen because of a perception of the subversion of formal parliamentary process. In other words, while there is a formal element to Sewel motions, their use has reflected the UK intergovernmental style of informal arrangements between executives. Further, the innocuous nature of most motions suggests that UK dominance is rarely a serious issue. ${ }^{13}$

However, the same can be said for the substance of most reverse-Sewel motions which merely allow Scottish ministers to implement policy established in a Westminster Act There are often tight parameters on Scottish action (in the Gambling Bill the decisions on the number and location of 'super-casinos' will be made in London), other ways to achieve legislative changes (as in Wales which has similar health profession regulators) and other ways to achieve the same outcomes (as in lottery fund distribution in Scotland). This leaves two particularly significant reverse-Sewel motions. The first allows Scottish ministers to direct Scottish local authorities on employment matters (as part of the agenda on the 'two-tier workforce' and public-private partnerships - see SPOR 6.2.03 Col 17837). The second allows for the transfer of responsibility (and consequent funding of over $£ 300$ million) for the Scottish rail network to Scottish ministers. Neither case 
suggests a huge 'victory' in an extension of Scottish powers and each represents a salient issue with little electoral gain.

The bottom-up narrative suggests that day-to-day autonomy in Scotland is reinforced by Scottish ministers seeking to 'make their mark' and shift the boundaries of the devolution settlement. However, this freedom to redefine or reframe may be exaggerated and political will in Scotland should be considered within the context of Whitehall acceptance of the policy issue. As Agranoff (2004: 30) argues, such autonomy rests 'on a foundation of supportive intergovernmental relations' and the experience of Hepatitis $\mathrm{C}$ has shown that Whitehall departments can obstruct policy on the basis of competence if they are concerned about the effects of Scottish action on the UK. In the case of smoking, while the UK Health Secretary merely expressed reservations about completely banning smoking in public places, civil servants within the Department of Health were far more supportive. Therefore, the Scottish bill was as much based on implicit UK support ${ }^{14}$ as an imaginative solution to devolved competence in Scotland.

This contingent nature of Scottish autonomy is demonstrated by the fact that health and safety policy as a whole is still reserved despite pressure within Scotland. The issue first arose after Woolfson and Beck (1999; see also Cathy Jamieson MSP, 2000) argued for Scottish Parliament intervention to address relatively high death and injury rates in Scotland. This was taken on by the Scottish Trades Union Council which argued that NHS provision (devolved) is deficient for workers since there are insufficient links to, and preventative work on, safety and occupational health (reserved). However, the Health and Safety Executive reacted unfavourably to the Woolfson and Beck report and has resisted health and safety devolution ever since. The Scottish Executive has also resisted including health and safety in the memorandum of understanding between it and the STUC, classing it as a reserved matter even though issues such as the penalties for assaulting emergency services workers are devolved.

The recent example of corporate homicide reinforces the reserved nature of health and safety. In December 2005 the Scottish Executive signalled the possibility of separate 
Scottish legislation going further than UK policy when identifying negligent individuals in senior positions in companies (the bill would also address the problem of identifying a 'controlling mind' in Scots law). This would require a successful purpose test: a demonstration that the primary aim of the legislation was to introduce a crime of deliberate negligent behaviour to increase public safety (devolved) as well as act as a deterrent effect in the area of health and safety of workers (reserved). However, unlike the issue of smoking, the issues had already been raised by the UK government which defined the problem in terms of health and safety. This definition did not shift despite extensive Scottish Executive activity. In what was described as a 'legal decision' (rather than a negotiation between executives) the problem was reserved to Westminster legislation (The Herald 18.7.06 'Westminster to rule on corporate killing').

The evidence in other policy areas is also mixed. While Scottish ministers may have the power of veto over new nuclear power stations in Scotland there is confusion about the basis of this power, either through executive devolution (under the Electricity Act 1989), concordat, or devolved planning laws. Media accounts tend to stress the use of planning law but the Executive's position on the basis of power is not clear in First Minister's Question Time (SPOR, 12.5.05, col. 16826-8). While the steps taken by the First Minister to demonstrate his power on this matter may reflect a maturing and more assertive Scottish Executive, such a step is unusual and may reflect prior agreements with Whitehall which are subject to change (see Cairney, 2006b: 73).

The issue of asylum seeking also appears to demonstrate significant Scottish involvement in a reserved issue, although in this case it may have been forced on reluctant Scottish ministers. As Davis (2005: 17) suggests, Scottish Executive attempts to treat the matter as a reserved issue (negotiated between the Home Office and local authorities) were largely successful until two crises - the murder of a Kurdish asylum seeker in 2001 and the fate of children within the Dungavel Detention Centre from 2003 to 2004 - forced the issue of Scottish ministerial involvement up the agenda. While the first crisis prompted ministers to take a formal interest in the delivery of devolved public services to asylum seekers, the latter demonstrated a firm Scottish Executive belief that most aspects of 
Dungavel - including the education of children - were reserved matters (2005: 22). ${ }^{15}$ Indeed, the result of civil society pressure in Scotland was the removal of detainees from Scotland back to England, rather than a shift in policy towards their treatment within Scotland. Therefore, if anything this example demonstrates the overarching influence of reserved policy on public service delivery in Scotland, based on strong interest in the UK and direction from Whitehall. This is well demonstrated by the more recent controversy over Scottish police forces (devolved) carrying out 'dawn raids' to expel unsuccessful asylum applicants on behalf of the Home Office. In this case, first ministerial statements to the Scottish Parliament on the prospect of a formal 'protocol' between the Scottish Executive and the Home Office - to make the process more 'humane' and include devolved welfare and social work services - appear to have been rebuffed by the Home Office (Cairney, 2006a: 20).

The example of international aid demonstrates more scope for Scottish initiative if there is political will to be involved and imaginative ways are sought to exploit blurred boundaries. While this matter as a whole is reserved, it is possible to develop a coherent Scottish response based on private fund-raising and using these funds to direct nongovernmental organisations operating abroad without infringing on reserved matters. However, again, the UK context is important in two ways. First, an extension of formal links between the Scottish Executive and Malawi may require Foreign Office support and Home Office clearance for (for example) medical training in Scotland. Second, the timing for the Malawi initiative coincided with Scotland's hosting of the G8 summit and the UK's strong pursuit of the poverty in Africa agenda. In other words, imaginative ways to work around reserved areas may not be necessary in the case of a devolved government furthering a UK ministerial agenda.

\section{Conclusion}

The comparative study of intergovernmental relations suggests that the UK exhibits an unusual combination of features - an asymmetry of population and power, a lack of a supreme constitution and a tendency to work informally through executives. Given the internalisation of decision-making and lack of formal dispute resolution producing 
'winners and losers', it is relatively difficult to assess the power of the centre in relation to the periphery. This is compounded by the evidence from multi-level governance - that power is dispersed and policy outcomes are the result of a complex series of negotiations between state and private interests at more than one level of government. In particular, the identification of 'first face' powers to win high profile arguments on reserved and devolved issues is qualified by the exercise of 'second face' powers to reframe policy problems and shift the decision-making venue. Therefore, while the study of IGR is useful in identifying key structures underpinning governmental relations, it does not limit the scope for variation in policy outcomes. As Agranoff (2004: 58) suggests, these vary in reflection of the power of devolved governments to initiate policy without central government constraint and the willingness of both parties to cooperate. To this we can add the strength or visibility of the agenda which affects not only the attention and cooperation from Whitehall, but also the willingness of Scottish ministers to push the limits of the devolution settlement

When the scope for variation of outcomes is so wide, the recourse to empirical investigation is crucial. However, more crucial still is the means to interpret specific results from a wider theoretical viewpoint. Hence the value of narratives as a means of exploring contrasting lenses through which to view IGR. The top-down narrative stresses UK dominance. It suggests that the informal nature of IGR reflects the power of the UK government to disengage from the process of devolution but still reserve the power to decide in high profile cases of disagreement. The use of Sewel motions reflects this dominance, with most issues of blurred boundaries addressed by venue shift back to Westminster and Whitehall. In contrast, the bottom up narrative highlights the discretion afforded by Barnett, the subtle victories on public finance that Scotland enjoys if it avoids confrontation, the extent of executive devolution afforded by Sewel, and the room for policy space if the Scottish Executive is willing to push the boundaries of the devolution settlement. In a sense this is a false or exaggerated debate and a combination of narratives suggests that the Sewel process suits the interests of both parties keen to present an image of 'seamless' devolution. Sewel says more about the relationship 
between executives and parliaments, demonstrated by the criticisms by both parliaments on the informal nature of IGR even when resolving formal legislative boundaries.

Yet, the value of the narratives is that, when combined with case-study analysis, they highlight the narrow constraints within which Scottish autonomy operates. With nuclear power Scottish discretion is afforded by executive devolution; with asylum we see a lack

of Scottish Executive willingness to intervene; and with international aid we see an executive furthering a UK agenda. Even in the most high profile case of Scotland 'reclaiming' a policy area (smoking in public places) we see that the action was underpinned by UK encouragement. Without such encouragement in other aspects of health and safety law the reserved nature of policy has never been successfully challenged. Perhaps ironically, this turns one finding from our introduction on its head. The distinction between power as capacity and the exercise of power may be used by MLG studies to challenge an assumption of UK power based on its formal structures. However, it can also be used to undermine the significance of venue shift based on the ability of the Scottish Executive to reframe issues. As Keating (2005: 10) points out, since social work reform is still cited as the key example of autonomy before devolution, perhaps 'not much worth noting had happened since'. It remains to be seen if the limited example of smoking remains the example of autonomy after devolution.

\section{References}

Agranoff, Robert (2004), 'Autonomy, Devolution and Intergovernmental Relations', Regional and Federal Studies, Vol.14, No.1, pp.26-65.

Bache, Ian and Mathew Flinders (eds) (2004) Multilevel Governance. Oxford: Oxford University Press.

Bache, Ian and Mathew Flinders (2004b), 'Multi-level Governance and the Study of the British State', Public Policy and Administration, Vol. 19, No. 1, pp.31-52

Baumgartner, Frank and Brian Jones (1993), Agendas and Instability in American Politics. Chicago: University of Chicago Press. 
Bell, David and Alex Christie (2001), 'Finance - The Barnett Formula: Nobody’s Child?' in Trench A (ed) (2001), The State of the Nations: The Second Year of Devolution in the $U K$. London: The Constitution Unit.

Bell, David and Christie, Alex (2005) 'Finance - Paying the Piper, Calling the Tune?' in A. Trench (ed), The Dynamics of Devolution. London: Imprint.

Bevir, Mark and R.A.W. Rhodes (1999), 'Studying British Government: Reconstructing the Research Agenda', British Journal of Politics and International Relations, Vol.1, No. 2, pp. 215-39.

Bulmer, Simon, Martin Burch, Caitrióna Carter, Patricia Hogwood, and Andrew Scott. (2002), British Devolution and European Policy-Making: Transforming Britain into Multi-Level Governance. Basingstoke: Palgrave.

Bulpitt, Jim (1983), Territory and Power in the United Kingdom. Manchester: Manchester University Press.

Cairney, Paul (2002), 'New Public Management and the Thatcher Health Care Legacy: Enough of the Theory, What about the Implementation?', British Journal of Politics and International Relations, Vol.4, No.3, pp.375-98.

Cairney, Paul (2005a), 'Submission to Procedures Committee Sewel Convention Inquiry',

http://www.scottish.parliament.uk/business/committees/procedures/inquiries/sewel/18cairney.htm

Cairney, Paul (forthcoming), 'Using Devolution to Set the Agenda? Venue shift and the smoking ban in Scotland', British Journal of Politics and International Relations Cairney, Paul (2006a) 'The Scottish Parliament' in (ed) Jones, Peter Scotland Devolution Monitoring Report January 2006 (London: The Constitution Unit) http://www.ucl.ac.uk/constitutionunit/research/devolution/Monitoring\%20Reports/Jan06/Scotland\%20Jan06.pdf Cairney, Paul (2006b) 'Public Policies' in (ed) Jones, Peter Scotland Devolution Monitoring Report May 2006 http://www.ucl.ac.uk/constitutionunit/research/devolution/MonReps/Scotland_May06.pdf Cairney, Paul and Michael Keating (2004), 'Sewel Motions in the Scottish Parliament', Scottish Affairs, Vol.47 (Spring), pp.115-34 
Clerking and Reporting Directorate (2002), Sewel Motions - Procedural and Practical Issues http://www.scottish.parliament.uk/business/committees/procedures/papers05/SMpaper1.pdf

Davis, Andrew (2005), 'Understanding the Effects of Asymmetric Institutional Design on the Policy Process', Paper to Political Studies Association Annual Conference, University of Leeds.

Greer, Scott (2004), Territorial Politics and Health Policy. Manchester: Manchester University Press.

Greer, Scott (2005a), 'Becoming European: Devolution, Europe and Health PolicyMaking', in A. Trench (ed), The Dynamics of Devolution. London: The Constitution Unit Greer, Scott (2005b), The New EU Health Policy and the NHS Systems. London: The Nuffield Trust http://www.nuffieldtrust.org.uk/ecomm/files/090205EUhealthsystem.pdf Himsworth, Chris (2004), 'The General Effects of Devolution Upon the Practice of Legislation at Westminster', Appendix 1 to House of Lords Select Committee on the Constitution $15^{\text {th }}$ Report of Session 2003-04 Devolution: Its Effect on the Practice of Legislation at Westminster (HL Paper 192). London: The Stationery Office.

Hindess, Barry (1995), Discourses of Power: from Hobbes to Foucault. (Oxford: Blackwell)

Hooghe, Liesbet and Gary Marks (2003a), Multi-level Governance and European Integration. Maryland: Rowman and Littlefield Hooghe, Liesbet and Gary Marks (2003b), 'Unravelling the Central State, but How? Types of Multi-level Governance', American Political Science Review, Vol. 97, No. 2, pp.233-43.

Horgan, Gerard (2004), 'Inter-institutional Relations in the Devolved Great Britain: Quiet Diplomacy', Regional and Federal Studies, Vol.14, No.1, pp.113-35.

House of Commons Library (2003), The West Lothian Question, http://www.parliament.uk/commons/lib/research/notes/snpc-02586.pdf

Jamieson, Cathy (2000), 'Health and Safety is a Holyrood issue', The Citizen http://www.thecitizen.org.uk/articles/vol2/article13a.htm Keating, Michael (2005) The Government of Scotland: Public Policy Making after Devolution. Edinburgh: Edinburgh University Press. 
Keating, Michael, Linda Stevenson, Paul Cairney, and Katherine Taylor (2003) 'Does Devolution Make a Difference? Legislative Output and Policy Divergence in Scotland', Journal of Legislative Studies, Vol.9, No. 3, pp. 110-39.

Kellas, James (1973), The Scottish Political System. Cambridge: Cambridge University Press.

Midwinter, Arthur (2004), 'Financing Devolution in Practice', Public Money and

Management Vol.24, No.3, pp.137-44.

Midwinter, Arthur, Michael Keating and James Mitchell (1991), Politics and Public Policy in Scotland. Basingstoke: MacMillan.

Mitchell, James (2003), Governing Scotland. Basingstoke: Palgrave.

Mitchell, James (2004), 'Scotland: Expectations, Policy Types and Devolution' in A. Trench (ed), Has Devolution Made a Difference? The State of the Nations 2004. London: Imprint

Page, Alan (2002), Memorandum and Evidence, House of Lords Select Committee on the Constitution, Devolution: Inter-Institutional Relations in the United Kingdom, Evidence complete to 10 July 2002, HL 147, pp.183-6

Page, Alan (2005), 'A Parliament that is Different? Law Making in the Scottish Parliament' in R. Hazell and R. Rawlings (eds) Devolution, Law Making and the Constitution. London: Imprint.

Page, Alan and Andrea Batey (2002), 'Scotland's Other Parliament: Westminster Legislation about Devolved Matters in Scotland since Devolution', Public Law, Autumn, pp.501-23.

Parry, Richard and Amy Jones (2000), 'The Transition from the Scottish Office to the Scottish Executive' Public Policy and Administration Vol. 15, No.2, pp.53-66.

Paterson, Lindsay (1994), The Autonomy of Modern Scotland. Edinburgh: Edinburgh University Press.

Procedures Committee of the Scottish Parliament (2005), The Sewel Convention, SP Paper 428, http://www.scottish.parliament.uk/business/committees/procedures/reports05/prr05-07-vol01.htm

Rhodes, R.A.W., Paul Carmichael, James McMillan and Andrew Massey (2003)

Decentralizing the Civil Service. Milton Keynes: Open University Press. 
Scottish Affairs Select Committee (2006) The Sewel Convention: the Westminster

Perspective

http://www.publications.parliament.uk/pa/cm200506/cmselect/cmscotaf/983/983.pdf

Scottish Executive. (2004a), A Breath of Fresh Air. Edinburgh: Scottish Executive

http://www.scotland.gov.uk/library5/health/abfa-00.asp

Scottish Executive. (2004b), Smoking in public places, a consultation on reducing

exposure to second hand smoke. Edinburgh: Scottish Executive

http://www.scotland.gov.uk/consultations/health/sippc-00.asp

Scottish Executive (2005), Corporate Homicide: Expert Group Report

http://www.scotland.gov.uk/Publications/2005/11/14133559/35592

Simeon, Rachel (2003), 'Free Personal Care. Policy Divergence and Social Citizenship', in R. Hazell (ed) The State of the Nations 2003. London: Imprint.

Trench, Alan (2004), 'Devolution: the withering-away of the Joint Ministerial Committee', Public Law, pp.513-517

Trench, Alan (2005), 'Washing Dirty Linen In Private: Disputes And The Mechanisms

Of Intergovernmental Relations In The United Kingdom', Paper presented at the Political

Studies Association conference, Leeds http://www.psa.ac.uk/2005/pps/Trench.pdf

Watts, Ronald (forthcoming), 'The United Kingdom as a Federalized or Regionalized

Union' in A. Trench (ed) Devolution and Power in the United Kingdom

Winetrobe, Barry (2001), 'Counter-Devolution? The Sewel Convention on Devolved

Legislation at Westminster', Scottish Law and Practice Quarterly, pp.286-92.

Winetrobe, Barry (2005), 'A Principled Approach to the Sewel Parliamentary Processes', Submission to Procedures Committee Sewel Convention Inquiry', http://www.scottish.parliament.uk/business/committees/procedures/inquiries/sewel/07winetrobe.htm

Woolfson, Charles and Matthias Beck (1999), 'Accidents at work: the Scottish anomaly', Occupational Safety and Health Vol. 29, No.12, pp.14-21.

\footnotetext{
${ }^{1}$ The Scotland Office was formed to act as a conduit between the Scottish Executive and Whitehall, and to administer certain reserved aspects of Scottish policy. The necessity of the office receded as the Scottish Executive became more effective. In June 2003 it was subsumed within the Department for Constitutional Affairs.

${ }^{2}$ Author calculations from www.scotland.gov.uk/Consultations/Archive
} 


\footnotetext{
${ }^{3}$ The Barnett formula, devised in the late 1970s, refers to a block grant based on spending patterns in devolved areas (at the time Scotland's spending was approximately $120 \%$ of the UK average) and a population-based formula to account for changes in English expenditure. The squeeze (when expenditure rises) refers to the erosion of Scotland's initial $120 \%$ settlement as any marginal increase is at the rate of $100 \%$. The formula appears to satisfy Scottish calls for funding based on higher need and English calls to reduce Scotland's share of expenditure in the long run.

${ }^{46}$ 'Fury at Reid's Hep C pay-out 'blackmail', The Scotsman, 24.1.04

${ }^{5}$ Presentation to ESRC conference on devolution, Edinburgh 18.3.05

${ }^{6}$ The Times, 8.12.04 'Executive 'has role in foreign issues'.

${ }^{7}$ The funding is contingent on housing stock transfer from councils to housing associations.

${ }^{8} \mathrm{~A}$ consequential is a payment made to Scotland when it is established that comparable English expenditure in a devolved area has taken place.

${ }^{9}$ This article draws on interviews with ministers, MSPs and pressure participants in the tobacco policy and health and safety fields.

${ }^{10}$ www.scotland.gov.uk/concordats/hse-00.asp

${ }^{11}$ See section 29.3 of the Scotland Act 1998 http://www.opsi.gov.uk/acts/en1998/98en46-d.htm

${ }^{12}$ See the Scottish Minister for Parliamentary Business' evidence to a House of Lords Inquiry in 2002 http://www.publications.parliament.uk/pa/ld200102/ldselect/ldconst/147/2051511.htm

${ }^{13}$ For example, one motion ensures the pension rights (reserved) of emergency service personnel (devolved) when engaged in international relief efforts (reserved).

${ }^{14}$ Perhaps furthering the pre-devolution use of Scotland as a 'guinea pig' for controversial policies.

${ }^{15}$ As with the health or education of armed forces based in Scotland.
} 